\title{
Chitinolytic Bacteria Isolated from Chili Rhizosphere: Chitinase Characterization and Application as Biocontrol for Aphis gossypii
}

\author{
NICHO NURDEBYANDARU, NISA RACHMANIA MUBARIK*, AND TARUNI SRI PRAWASTI \\ Department of Biology, Faculty of Mathematics and Natural Sciences, Institut Pertanian Bogor, \\ Darmaga Campus, Bogor 16680, Indonesia
}

\begin{abstract}
Chitin, a common constituent of insect exoskeleton, could be hydrolyzed by chitinase. This research was conducted to select rhizobacteria isolated from the rhizosphere of chili pepper that produced chitinase and to examine their chitinase activity in degrading chitin of the Aphis gossypii. A total of 25 rhizobacteria isolates formed a clear zone when grown on chitin agar. Three of them had the highest chitinolytic index and were identified as Bacillus sp. strain I.5, I.21, and II.14. The II.14 was chosen for characterization of chitinase activity. The isolate showed maximum chitinase activity at 48 -h-incubation. Maximum temperature and $\mathrm{pH}$ of the chitinase activity were $55^{\circ} \mathrm{C}$ and 7.0, respectively. The cell culture and the enzyme crude extract of the above three isolates were tested against $A$. gossypii and the result was compared to the control through microscopic observation. Hydrolytic analysis showed that the enzyme crude extract of these isolates were able to degrade chitin of insect exoskeleton since the first 3-h-incubation. Meanwhile, the cell culture treatment on the chitin showed degrading activity after $12 \mathrm{~h}$ (Bacillus sp. strain I.21 and II.14), and $9 \mathrm{~h}$ (Bacillus sp. strain I.5). Chitin degradation of A. gossypii exoskeleton by enzyme crude extract was better than the cell culture treatment. Chitinases produced by Bacillus sp. strains I.5, I.21, and II.14 are potential as biocontrol agents for $A$. gossypii.
\end{abstract}

Key words: rhizobacteria, chitinase, biocontrol, Aphis gossypii

Aphis gossypii or melon aphid or cotton aphid was one of the leaf miners that attack many kinds of plants, including chili pepper. Chili peppers attacked by the aphids have wrinkled leaf, obstructed shoot, and damaged leaf tissue caused by the chili veinal mottle virus (CVMV) carried by adult aphids. Chili pepper yields may decrease up to $60 \%$ due to the attack of this virus (Wagiman et al. 2001). A. gossypii is the most effective vector for viruses; aside of CVMV, the aphid also takes part as a vector for cucumber mosaic virus (Garzo et al. 2003).

Insectiside have been used in high frequency to control pest, but the limitation in chemical control is increasing due to a rapid development of insectiside resistance and also the accumulation of chemical residue is difficult to degrade. Therefore, biological control has been chosen as an alternative to reduce chemical pesticides usage. Root colonizing bacteria (rhizobacteria) that exert beneficial effects on plant development via direct or indirect mechanisms have been defined as plant growth-promoting rhizobacteria (PGPR). The PGPR may become a promising biocontrol agent for plant diseases. Large scale application of PGPR to crop as inoculants will substantially reduce the use of chemical fertilizers and pestisides, which often pollute the environment (Bloemberg and Lugtenberg 2001).

Chitin is the most abundant polymer after cellulose. It is a common constituent of algae and fungal cell walls, insects, and nematodes. Insect's exoskeleton or cuticle is composed of chitin. The cuticle is divided into three layers, namely the cover layer, epicuticle, and procuticle (Merzendorfer and Zimoch 2003; Schwarz and Moussian 2007). Chitinases (EC 3.2.1.14) hydrolyse the glycosidic $-1,4$ bonds in chitin to its oligomer or monomer and are found in a broad range of

*Corresponding author, Phone/Fax: +62-251-8622833; Email: nrachmania@ipb.ac.id organisms, including bacteria, fungi, and higher plants, and play different roles in their origin (Lonhienne et al. 2001; Funkhouser and Aronson 2007).

The presence of chitinolytic bacteria in the crop rhizosphere soils is highly beneficial as they are able to suppress plant pathogenic fungi near the root zone and provide sustainable plant protection against root diseases. Saikia et al. (2005) reported the presence of PGPR Pseudomonas sp. that produced chitinase and -1,3-glucanase and showed ability in inhibiting the growth of Fusarium oxysporum.

Previous research by Mubarik et al. (2010) showed that the chitinase of Bacillus sp. strain I.5 and I.21 showed their ability to degrade exoskeleton chitin of the whitefly Bemisia tabaci. The objectives of this research are to screen potential PGPR from pepper rhizosphere that produce extracellular chitinase and to use the enzyme for controlling leaf miner such as A. gossypii.

\section{MATERIALS AND METHODS}

Bacteria and Test-Objects. Twenty five bacteria isolates from the rhizosphere of chili pepper (Damayanti et al. 2007) were collected at Microbiology Laboratory of Biology Department, Faculty of Mathematics and Natural Sciences, Institut Pertanian Bogor (IPB) and IPB Culture Collection. A. gossypii were obtained from suffering plants around IPB.

Bacterial Growth Media and Chitinolytic Bacteria Selection. Twenty five PGPR from the rhizosphere of chili pepper were grown on nutrient agar and incubated for $48 \mathrm{~h}$ at $37^{\circ} \mathrm{C}, \mathrm{pH} 7.0$. Each isolate was reinoculated to chitin agar ( $1 \%$ colloidal chitin, $0.1 \% \mathrm{MgSO}_{4} \cdot 7 \mathrm{H}_{2} \mathrm{O}, 0.02 \% \mathrm{~K}_{2} \mathrm{HPO}_{4}$, $0.1 \%$ yeast extract, and $1.5 \%$ agar) and incubated for $48 \mathrm{~h}$ at $37^{\circ} \mathrm{C}, \mathrm{pH}$ 7.0. The isolates were screened based on chitinolytic index, defined as the ratio of clear zone to colony diameter on nutrient agar. The identification of bacterial isolate was carried 
out based on morphological structure, Gram staining, endospore staining, and catalase test.

Bacterial Growth Curve and Enzyme Production. A number of $10^{8}$ cells $\mathrm{mL}^{-1}$ of selected isolate was inoculated to production media consisting of $0.3 \%$ colloidal chitin, $0.1 \%$ $\mathrm{MgSO}_{4} \cdot 7 \mathrm{H}_{2} \mathrm{O}, 0.02 \% \mathrm{~K}_{2} \mathrm{HPO}_{4}$, and $0.1 \%$ yeast extract. The culture was incubated on a dry shaker at $37^{\circ} \mathrm{C}$ and $100 \mathrm{rpm}$. Cell cultures were collected every $12 \mathrm{~h}$ until $96 \mathrm{~h}$ and their density were measured spectrophotometerically at $600 \mathrm{~nm}$. The cultures were then centrifuged at $8400 \mathrm{x}$ g for $10 \mathrm{~min}$ to obtain the crude extract of extracellular chitinase enzyme in supernatant.

Chitinase Activity and Protein Quantity Measurement. Chitinase activity was measured as described by Spindler (1997). A volume of $450 \mu \mathrm{L}$ enzyme crude extract was added to $900 \mu \mathrm{L} 0.3 \%$ colloidal chitin and $450 \mu \mathrm{L} 0.1 \mathrm{M}$ phosphate buffer. The mixture was incubated at $55^{\circ} \mathrm{C}$ for $30 \mathrm{~min}$. Enzyme reaction was stopped at $100^{\circ} \mathrm{C}$ for $10 \mathrm{~min}$. After centrifugation at $8400 \mathrm{x}$ g for $5 \mathrm{~min}, 600 \mu \mathrm{L}$ filtrate was added to $1.5 \mathrm{~mL}$ distilled water and $3 \mathrm{~mL}$ Schales reagent, and the mixture was boiled at $100^{\circ} \mathrm{C}$ for $10 \mathrm{~min}$. Enzyme activity was determined by measuring absorbance at $420 \mathrm{~nm}$. One unit of enzyme activity was defined as the amount of enzyme which released $1 \mu$ mol reducing sugar (N-acetyl glucosamine) per min. Protein content was determined using as describe by Bradford (1976). Bovine serum albumin was used as a protein standard.

Chitinase Characterization. Enzyme characterization was done to define optimum $\mathrm{pH}$ and temperature of chitinase activity. Chitinase activity was measured at $\mathrm{pH}$ ranging from 4 to 10 using $0.1 \mathrm{M}$ citrate buffer ( $\mathrm{pH} 4.0-6.0), 0.1 \mathrm{M}$ phosphate buffer ( $\mathrm{pH} 7.0-8.0$ ), and $0.1 \mathrm{M}$ glycine- $\mathrm{NaOH}$ buffer ( $\mathrm{pH} 9.0-10.0)$. The effect of temperature on chitinase activity was measured at temperature ranging from $25-60^{\circ} \mathrm{C}$ using $5^{\circ} \mathrm{C}$ interval at optimum $\mathrm{pH}$ obtained from previous experiment. The data were based on duplicate experiments.

Chitinase Test to Aphis gossypii. Live aphids were selected based on their shape and size. Aphids with the same size were assumed as aphids of the same age and chitin thickness. The test were done by dropping $20 \mu \mathrm{L}$ cells supernatant and $20 \mu \mathrm{L}$ enzyme crude extract to each aphid at room temperature. Chitin hydrolysis was observed every $3 \mathrm{~h}$ until $24 \mathrm{~h}$ by comparing the thickness of chitin layer on each aphid (Mubarik et al. 2010). Treated aphid were first fixed with $70 \%$ ethanol for $24 \mathrm{~h}$ and then serially dehydrated for 10 min with 80,95 , and $100 \%$ ethanol. Clove oil was dropped onto the aphids for $15 \mathrm{~min}$ and cleaned with xylol. Each aphid was placed on the object glass, then covered and tightened with synthetic resin Entellan (a particularly rapid embedding agent). Chitin thickness was observed with light microscope at 40 times magnification.

\section{RESULTS}

Chitinolytic Index. A total of 25 PGPR isolates were obtained from the rhizosphere of chili pepper. They formed a clear zone when grown on chitin agar. It showed that they all produced extracellular chitinases that could hydrolyze chitin in the media. Among the 25 chitinolytic bacteria, only 3 isolates produced $0.5 \mathrm{~cm}$ clearing zone, i.e. I.5, I.21, and II.14. Interestingly, the isolates also had both proteolytic and cellulolytic activities (Table 1). Chitinase activity and characterization of I.5 and I.21 had been reported by Mubarik et al. (2010). Therefore in this research only characterization of II.14 chitinase activity were described, and the isolate is a Gram-positive, endospore forming, rod shaped bacterium with catalase positive reaction. Based on the physical characteristics, the isolates are most likely belonging to Bacillus sp. (Holt et al. 1994).

Growth Curve and Chitinase Activity of II.14 Isolate. The isolate was grown in liquid chitin media at $\mathrm{pH} 7.0$ and $37^{\circ} \mathrm{C}$. The growth rate of isolate II. 14 ascended from $0-24 \mathrm{~h}$ incubation and was relatively stable for 24-84 h, and descended afterwards (Fig 1). The chitinase produced was detected since the $24^{\text {th }} \mathrm{h}$ and the highest chitinase activity were found at the $48^{\text {th }} \mathrm{h}$, after $60 \mathrm{~h}$ the activity was not detected (Fig 1). The activity of the isolate was measured at $55^{\circ} \mathrm{C}$ pH 7.0.

Characterization of Chitinase from II.14 Isolate. Among the different temperature tested, maximum chitinase activity was observed at $55^{\circ} \mathrm{C}$ being 0.115 unit per $\mathrm{mg}$ protein. There were no chitinase activity lower than $30^{\circ} \mathrm{C}$ and between $30-50^{\circ} \mathrm{C}$ (Fig 2). Among different $\mathrm{pH}$ values tested, at $\mathrm{pH} 7.0$ the enzyme showed maximum activity of 0.1 unit per mg protein. There was no chitinase activity at pHs lower than 5.0 and higher than 8.0 (Fig 3).

Table 1 Chitinolytic index of rhizobacteria isolates

\begin{tabular}{|c|c|c|c|c|c|}
\hline \multirow[b]{2}{*}{ Isolate } & \multirow{2}{*}{$\begin{array}{l}\text { Colony } \\
\text { diameter } \\
(\mathrm{cm})\end{array}$} & \multirow{2}{*}{$\begin{array}{c}\text { Clear } \\
\text { zone } \\
\text { diameter } \\
(\mathrm{cm})\end{array}$} & \multirow{2}{*}{$\begin{array}{l}\text { Chitinolytic } \\
\text { index }\end{array}$} & \multicolumn{2}{|c|}{ Other hydrolytic index } \\
\hline & & & & $\begin{array}{l}\text { Proteolytic } \\
\text { index }\end{array}$ & $\begin{array}{l}\text { Cellulolytic } \\
\text { index }\end{array}$ \\
\hline I. 1 & 0.88 & 0,90 & 0.02 & 0.16 & - \\
\hline I. 2 & 0.70 & 0.70 & 0.00 & 0.06 & - \\
\hline I. 3 & 0.80 & 0.90 & 0.13 & 0.12 & 0.15 \\
\hline I. 4 & 0.85 & 0.90 & 0.06 & - & - \\
\hline I.5 & 0.60 & 1.20 & 1.00 & 0.51 & 0.10 \\
\hline I. 8 & 0.76 & 0.80 & 0.05 & - & - \\
\hline I. 14 & 0.96 & 1.00 & 0.04 & - & - \\
\hline I. 15 & 0.66 & 0.71 & 0.08 & 0.38 & - \\
\hline $\mathrm{I} .21$ & 0.70 & 1.30 & 0.86 & 0.82 & 0.18 \\
\hline I. 25 & 0.52 & 0.69 & 0.33 & 1.08 & 0.08 \\
\hline I. 26 & 0.87 & 0.97 & 0.11 & 0.13 & - \\
\hline I. 28 & 0.59 & 0.65 & 0.10 & 1.00 & - \\
\hline I. 33 & 0.57 & 0.60 & 0.05 & - & - \\
\hline I. 34 & 0.81 & 0.92 & 0.14 & 0.63 & 0.25 \\
\hline II.7 & 0.62 & 0.65 & 0.05 & - & - \\
\hline II. 8 & 0.94 & 1.00 & 0.06 & - & - \\
\hline II.10 & 0.84 & 0.92 & 0.10 & - & - \\
\hline II.11 & 0.59 & 0.65 & 0.10 & - & - \\
\hline II.12 & 0.75 & 0.77 & 0.03 & - & - \\
\hline II.13 & 0.76 & 0.79 & 0.04 & - & 0.05 \\
\hline II.14 & 0.60 & 1.05 & 0.75 & 0.28 & 0.40 \\
\hline II.15 & 1.00 & 1.10 & 0.10 & - & - \\
\hline II.16 & 0.65 & 0.67 & 0.03 & - & - \\
\hline II.17 & 0.57 & 0.58 & 0.02 & - & - \\
\hline II. 34 & 0.90 & 0.99 & 0.10 & - & - \\
\hline
\end{tabular}




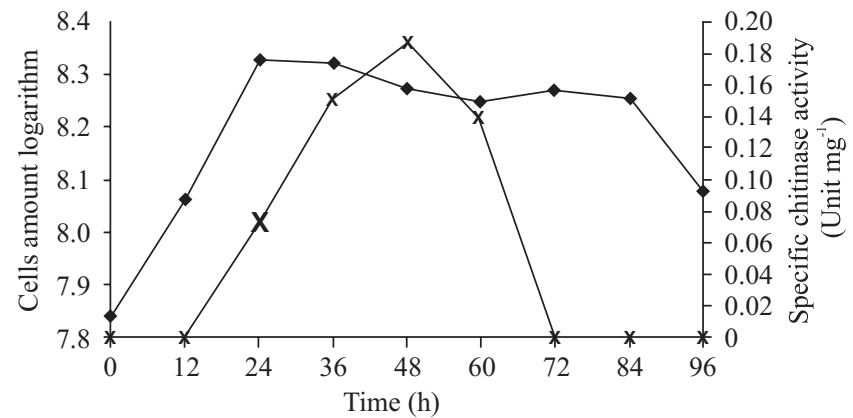

Fig 1 Growth and chitinase activity of II.14 isolate on production media enriched with colloidal chitin. - Log of cell number; $x$ specific chitinase activity.

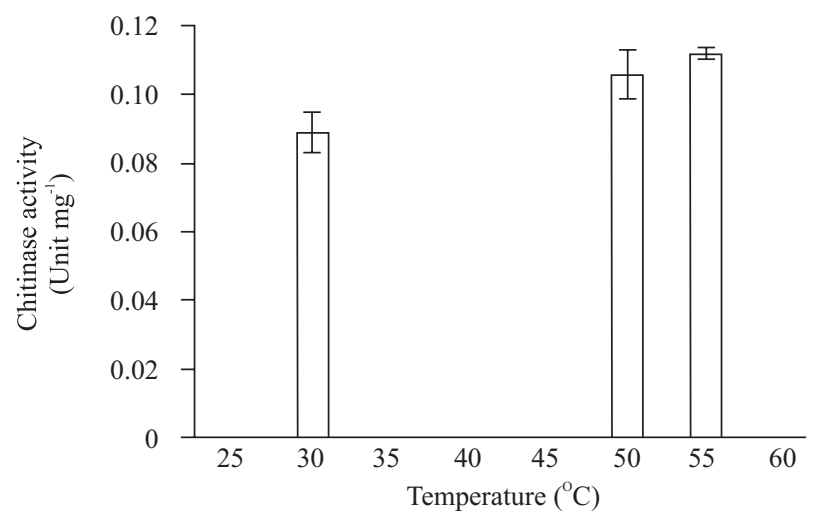

Fig 2 Effect of temperature on chitinase activity of II.14 isolate.

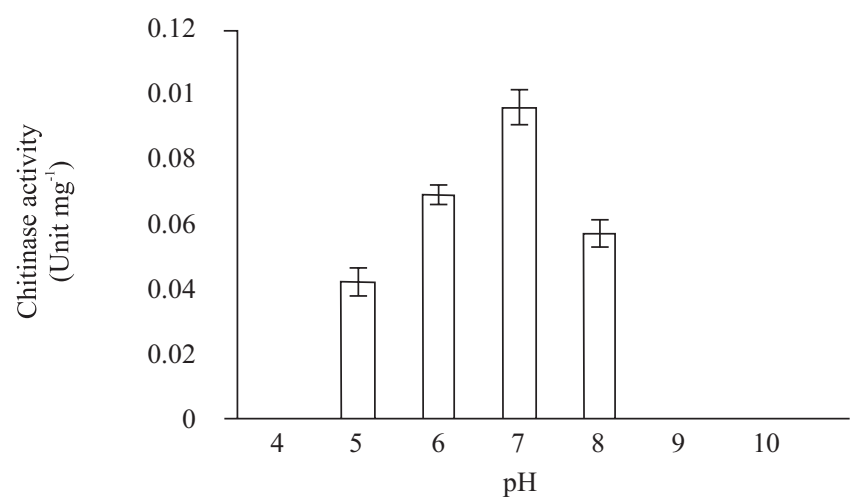

Fig 3 Effect of $\mathrm{pH}$ on chitinase activity of II.14 isolate.
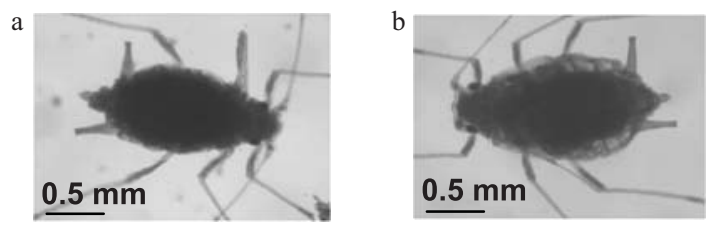

Aphid Chitin Hydrolysis. Chitinases from I.5, I.21, and II.14 isolates were used to observe their activities on the aphids' exoskeleton. Microscopic observation showed that the aphid exoskeleton were thinner in the presence of enzymes. This was even observed at $3 \mathrm{~h}$ after treatments. Treatment with the free cell supernatant made the exoskeleton thinner $12 \mathrm{~h}$ (I.21 and II.14) and $9 \mathrm{~h}$ (I.5) after treatment. The thickness of aphids' exoskeleton after treatments with chitinase or the cell culture were significantly different compared to the control (Fig 4).

\section{DISCUSSION}

Shanmugaiah et al. (2008) reported that among the 39 chitinolytic bacteria isolated from rice rhizosphere, only 11 isolates produced clearing zone over $0.5 \mathrm{~cm}$ on the chitin colloidal agar. Chitinase produced by $B$. laterosporus showed the highest clear zone of $1.1 \mathrm{~cm}$ around the colony in chitin colloidal agar. In this research, among the 25 chitinolytic bacteria, only 3 isolates produced clearing zone over $1.05 \mathrm{~cm}$ with chitinolytic index over 0.5 , i.e. I.5, I.21, and II.14. All isolates most likely belong to Bacillus sp. (Holt et al. 1994). Chitinase production was reported in different species of Bacillus such as B. amyloliquefaciens (Sabry 1992), B. cereus (Huang et al. 2005), B. circulans (Chen et al. 2004), B. licheniformis (Waldeck et al. 2006), B. megaterium (Sabry 1992), B. stearothermophilus (Sakai et al. 1994), B. subtilis (Wang et al. 2006), B. thuringiensis sub sp. aizawai (Vega et al. 2006), and B. thuringiensis sub sp. kurstaki (Driss et al. 2005).

Previous reports have shown that PGPR Bacillus sp. strain I.5 and I.21 demonstrated their ability to degrade exoskeleton chitin of whitefly Bemisia tabaci (Mubarik et al. 2010). However, this is the first report on the production of chitinase by Bacillus sp. strain II.14 and its application to degrade exoskeleton of aphid A. gossypii. Cell culture and chitinase of 1.5 and 1.21 isolates were used as comparison.

II.14 isolate secreted chitinase that were induced by the presence of substrates such as colloidal chitin. The highest specific activity was observed at the stationary phase, when the cell density began to decrease after $48 \mathrm{~h}$ incubation. From this time on, the activity started to decrease and no activity was detected after $72 \mathrm{~h}$ until the end of observation
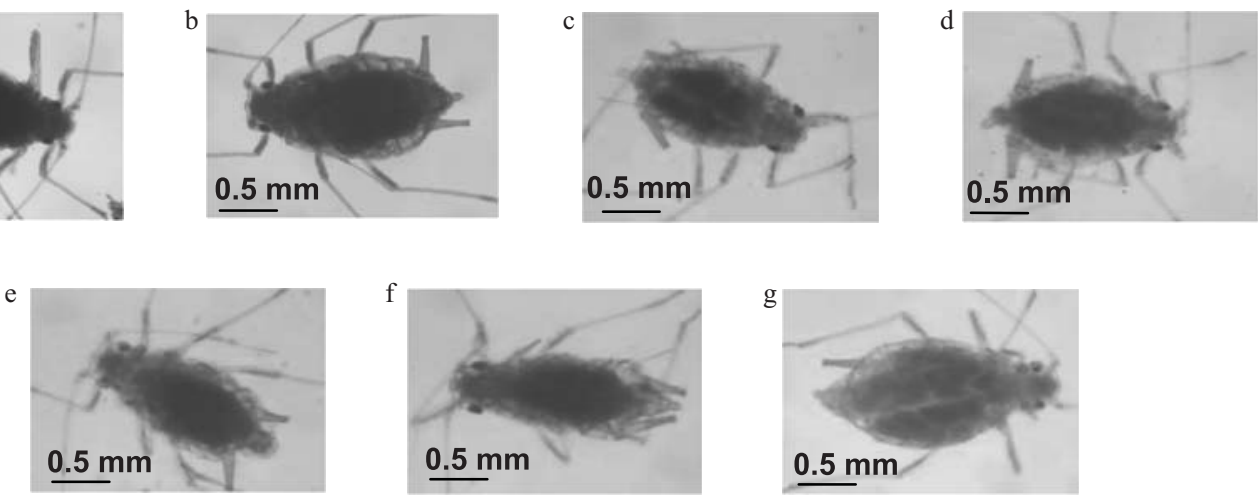

Fig 4 Aphids without treatments or control (a), cell culture treatment (b-d), enzyme treatment (e-g). Cell culture treatment of I.5 isolate at $9 \mathrm{~h}$ after treatment (b), I.21 isolate at $12 \mathrm{~h}$ (c), II. 14 isolate at 12 (d). Enzyme treatment isolated fromI.5 isolate at $3 \mathrm{~h}$ after treatment (e), I.21 isolate at $3 \mathrm{~h}$ (f), II. 14 isolate at $3 \mathrm{~h}(\mathrm{~g})$. Microscope observation was conducted with 40 times magnification. 
(96 h). It was estimated that after $72 \mathrm{~h}$, the bacterial culture were already at the end of stationary phase and in the beginning of death phase. The enzymes were no longer produced and toxic metabolites, such as antibiotic, were detected in stationary phase.

Chitinase activity was measured using the method of Spindler (1997). This method defines the amount of N-acetyl glucosamine formed following hydrolysis, which is then mixed with Schales reagent $\left[0.05 \% \mathrm{~K}_{3} \mathrm{Fe}_{3}(\mathrm{CN}) 6\right.$ and $5.3 \%$ $\left.\mathrm{Na}_{2} \mathrm{CO}_{3}\right]$ and measured with spectrophotometer. Low chitinase activity shows that there are a high amount of unhydrolyzed chitins and little amount of released $\mathrm{N}$-acetyl glucosamine. Chitinase of II. 14 had the highest activity at $55^{\circ} \mathrm{C}$. Chitinase activity of I. 21 and I.5 were also measured at $55^{\circ} \mathrm{C}$ (Mubarik et al. 2010). Chitinase of II. 14 also showed activity at $30^{\circ} \mathrm{C}$ and $50^{\circ} \mathrm{C}$, but not as high as at $55^{\circ} \mathrm{C}$. There was no chitinase activity at $30-50^{\circ} \mathrm{C}$. We assumed there were more than one chitinase molecules in the crude enzymes that had optimum activity at 30 and $55^{\circ} \mathrm{C}$. Chitinases have been isolated from a variety of bacteria, including Bacillus spp. and some of them were reported to produce multiple forms of chitinases with different molecular masses (Sanmugaiah et al. 2008).

Enzyme activity was also affected by $\mathrm{pH}$. Chitinase of isolate II. 14 showed activity at $\mathrm{pH}$ 5.0-8.0. The highest activity was observed at $\mathrm{pH}$ 7.0. Bacterial chitinase generally shows optimum activity at low pH (Ueda and Arai 1992; Evvyernie et al. 2000; Natsir 2000), but some also reported optimum activity at neutral pH (Wang and Chang 1997; Purwani 2004).

Chitin hydrolization test against Bemisia tabaci showed that cell cultures and chitinase crude extracts of isolate I.5 and I.21 were able to hydrolyse the insect's exoskeleton (Mubarik et al. 2010). This research analysed the ability of cell culture and chitinases of I.5, I.21, and II.14 isolate to degrade the exoskeleton of leaf miner A. gossypii. Damage level was caused by the treatment were observed at every $3 \mathrm{~h}$ for $24 \mathrm{~h}$. Crude extracts worked better than the cell cultures in degrading chitin. Microscopic observation showed that aphids cuticle were hydrolyzed at $3 \mathrm{~h}$ after treatment. Cell culture treatment showed that the hydrolysis started after $12 \mathrm{~h}$ (I.21 and II.14) and after 9 h (I.5) after treatment. It showed that chitinase were faster than the cell cultures in hydrolyzing the cuticles. In cell cultures treatment, more time is needed by the cells to produce chitinase, while the chitinase treatment made it possible to directly hydrolyse the chitin in exoskeleton. Dark exoskeletons were degraded and became more transparent, therefore objects with higher transparency showed a higher level of hydrolyzed chitin.

Chitinases-encoding gene may be cloned into high economy plant. Expression of the chitinase genes on tomato plants decreased the growth of Colorado potato beetle (Lawrence and Novak 2006). Koga (2005) reported that transgenic strawberry plants carrying chitinase gene were resistant to pathogenic fungi. Chitinase genes transformation on papaya increased its resistancy to red spiders (McCafferty et al. 2006). However, the general attitude of Indonesians toward transgenic plants is still not positive (Abbas 2003).

I.5, I.21, and II.14 isolates showed their ability to degrade chitin of A. gossypii. Chitin degradation with enzyme treatment was better than the cell culture treatment. Chitinase produced by the three selected isolates were potential to be improved and used as a biocontrol agent for insect such as aphid A. gossypii. Application of chitinase may be done by spraying the enzyme directly to the plants. Leaves and fruits of chitinase-sprayed-strawberry showed no presence of any insects or pathogenic fungi (Koga 2005). Combination between chitinase and $\sigma$-toxin of $B$. thuringiensis were found more effective in killing pest insects (Patil et al. 2000). Spreading chitin surrounding the plant is also an alternative, as this will induce chitinolytic rhizosphere bacteria to secrete chitinase (Metcalfe et al. 2002).

\section{REFERENCES}

Abbas N. 2003. Controversion around the food product as a result of genetically modified organism. Analis 4:41-7.

Bloemberg GV, Lugtenberg BJJ. 2001. Molecular basis of plant growth promotion and biocontrol by rhizobacteria. Curr Opin Plant Biol 4:343-50.

Bradford MM. 1976. A rapid and sensitive method for the quantitation of microgram quantities of protein utilizing the principle of protein dye binding. Anal Biochem 72:248-54.

Chen CY, Wang YH, Huang CJ. 2004. Enhancement of the antifungal activity of Bacillus subtilis F29-3 by the chitinase encoded by Bacillus circulans chiA gene. Can J Microbiol 50:451-4.

Damayanti TA, Pardede H, Mubarik NR. 2007. Utilization of rootcolonizing bacteria to protect hot-pepper against Tobacco Mosaic Tobamovirus. Hayati J Biosci 14: 105-109.

Driss F, Kallassy-Awad M, Zouari N, Jaoua S. 2005. Molecular characterization of a novel chitinase from Bacillus thuringiensis subsp. kurstaki. JAppl Microbiol 99:945-53.

Evvyernie D, Yamazaki S, Morimoto K, Karita S, Kimura T, Sakka K, Ohmiya K. 2000. Identification and characterization of Clostridium paraputrificum M-21, a chitinolitic, mesophilic, and hydrogen producing bacterium. Biosci Bioeng 89:596-601.

Funkhouser JD, Aronson NN. 2007. Chitinase family GH18: evolutionary insights from the genomic history of a diverse protein family. BMC Evol Biol 7:96-111.

Garzo EI, Diaz B, Duque M, Fereres A. 2003. Settlement rate of Aphis gossypii (Hemiptera, Aphididae) and transmissionefficiency of Cucumber Mosaic Virus in melons protected with kaolin-particle films. Span J Agric Res 4:65-71.

Holt JG, Krieg NR, Sneath PHA, Staley JT, Williams ST. 1994. Bergey's Manual of Determinative Bacteriology. $9^{\text {th }}$ ed. Baltimore: Williams \& Wilkins.

Huang CJ, Wang TK, Chung SC, Chen CY. 2005. Identification of an antifungal chitinase from a potential biocontrol agent, Bacillus cereus 28-9. J Biochem Mol Biol 38:82-8.

Koga D. 2005. Application of chitinase in agriculture. J Met Mater Miner 15:33-6.

Lawrence SD, Novak NG. 2006. Expression of poplar chitinase in tomato leads to inhibition of development in Colorado potato beetle. Biotechnol Lett 28:593-9.

Lonhienne T. 2001. Cloning, sequences, and characterization of two chitinase genes from the antarctic Arthrobacter sp. strain TAD20: isolation and partial characterization of the enzymes. J Bacteriol 183:1773-9.

McCafferty HR, Moore PH, Zhu YJ. 2006. Improved Carica papaya tolerance to carmine spider mite by the expression of Manduca sexta chitinase transgene. Trans Res 15:337-47.

Merzendorfer H, Zimoch L. 2003. Chitin metabolism in insects: structure, function and regulation of chitin synthases and chitinases. J Exp Biol 206:4393-412.

Metcalfe AC, Krsek M, Gooday GW, Prosser J, Wellington EMH. 2002. Molecular analysis of a bacterial chitinolytic community in an upland pasture. Appl Environ Microbiol 68:5042-50. 
Mubarik NR, Mahagiani I, Anindyaputri A, Santoso S, Rusmana I. 2010. Chitinolytic bacteria isolated from chili rhizosphere : chitinase characterization and its application as biocontrol for whitefly (Bemisia tabaci Genn.). Am J Agr Biol Sci 5:430-5.

Natsir H, Chandra D, Rukayadi Y, Suhartono MT, Hwang JK, Pyun YR. 2002. Biochemical characteristics of chitinase enzyme from Bacillus sp. of Kamojang crater, Indonesia. J Biochem Mol Biol Biophys 6:279-82.

Patil RS, Ghormade V, Desphande MV. 2000. Chitinolytic enzymes: an exploration. Enzyme Microb Technol 26:473-83.

Purwani EY, Suhartono MT, Rukayadi Y, Hwang JK, Pyun YR. 2004. Characteristics of thermostable chitinase enzymes from the Indonesian Bacillus sp. 13.26. Enzyme Microb Technol 35:147-53.

Sabry SA. 1992. Microbial degradation of shrimp-shell waste. J Basic Microbiol 32:107-11.

Saikia R, Singh BP, Kumar R, Arora DK. 2005. Detection of pathogenesisrelated proteins-chitinase and $b$-1,3-glucanase in induced chickpea. Curr Sci 89:659-66

Sakai K, Narihara M, Kasama Y, Wakayama M, Moriguchi M. 1994. Purification and characterization of thermostable beta-Nacetylhexosaminidase of Bacillus stearothermophilus $\mathrm{CH}-4$ isolated from chitin-containing compost. Appl Environ Microbiol 60:2911-5.

Schwarz H, Moussian B. 2007. Electron microscopic and genetic dissection of arthropod cuticle differentiation. In: Mendez-Villas, Diaz $\mathrm{J}$, editors. Modern research and educational topics in microscopy. Tuebingen: Formatex. p 316-25.
Shanmugaiah V, Mathivanan N, Balasubramanian N, Manoharan PT. 2008 Optimization of cultural conditions for production of chitinase by Bacillus laterosporous MML2270 isolated from rice rhizosphere soil. Af J Biotechnol 15:2562-8.

Spindler KD. 1997. Chitinase and chitosanase assays. In: Muzarelli RAA, MG Peter, editors. Chitin Handbook. Grottamare: Alda Tecnografica. p 229-35.

Ueda M,Arai M. 1992. Purification and some properties of chitinase from Aeromonas sp. No. 10S-24. Biosci Biotech Biochem 56:460-4.

Vega LM de la, Barboza-Corona JE, Aguilar-Uscanga MG, Ramirez-Lepe M. 2006. Purification and characterization of an exochitinase from Bacillus thuringiensis subsp. aizawai and its action against phytopathogenic fungi. Can J Microbiol 52:651-7.

Wagiman FX, Hussein MY, Muhamad R, Sajap AS, Ismail A. 2001. Age structure of aphidophagous Menochilus sexmaculatus Fabricius and Aphis gossypii Glover. Hayati 8:1-4.

Waldeck J, Daum G, Bisping B, Meinhardt F. 2006. Isolation and molecular characterization of chitinase deficient Bacillus licheniformis strains capable of deproteinization of shrimp shell waste to obtain highly viscous chitin. Appl Environ Microbiol 72:7879-85.

Wang SL, Chang WT. 1997. Purification and characterization of two bifunctional chitinases/lysozymes extracellularly produce by Pseudomonas aeruginosa K-187 in a shrimp and crab shellpowder medium. Appl Environ Microbiol 63:380-6.

Wang SL, Lin TY, Yen YH, Liao HF, Chen YJ. 2006. Bioconversion of shellfish chitin wastes for the production of Bacillus subtilis W-118 chitinase. Carbohydr Res 341:2507-15. 